\title{
The Pashtun Counter-Narrative
}

\section{Shah Mahmoud Hanifi}

To cite this article: Shah Mahmoud Hanifi (2016): The Pashtun Counter-Narrative, Middle East Critique, DOI: 10.1080/19436149.2016.1208354

To link to this article: http://dx.doi.org/10.1080/19436149.2016.1208354

曲 Published online: 18 Jul 2016.

Submit your article to this journal

Q View related articles $₫$

View Crossmark data \lceil 


\title{
The Pashtun Counter-Narrative
}

\author{
SHAH MAHMOUD HANIFI \\ James Madison University, Harrisonburg, VA, USA
}

\begin{abstract}
THIS article provides a critical appraisal of ethnicity as the primary route to knowing Afghanistan. The critique is founded on the fundamental voiceless-ness of Pashtuns in academic and international discussions about them. It utilizes longue durée history to amplify the salience of migration as an alternate framework for understanding Afghanistan, and it analyzes the place of the Pashto language in the modern Afghan state structure. The article also discusses the impact of the nineteenth-century British Indian colonial authority Mountstuart Elphinstone and the twentieth-century American specialist Louis Dupree to illustrate the persistence of Orientalism in Anglo-American imperial knowledge about Afghanistan.
\end{abstract}

Key Words: Afghanistan; Louis Dupree; Mountstuart Elphinstone; ethnicity; migration; orientalism; Pashto; Pashtuns

The aim of this article is to prompt readers to question commonly held assumptions and representations of Afghanistan. It is designed to help readers think more critically about the country, and as such some may find it to be more complicating than clarifying. In rhetorical terms, the following can be considered a polemic in that it strikes an oppositional posture in relationship to an all-too-standardized historical and cultural narrative that is woven around the theme of Pashtun ethnic domination of Afghanistan. That is, it offers a counter-narrative to the thesis of Pashtun domination of the country. It does so mainly by exploring cultural (primarily linguistic) and historiographical evidence and argumentation. I begin my critique with a frontal assault on a primary predicate of the normative discourse about Afghanistan, the issue of domination. The invocation of Pashtun ethnic dominance of the country occurs most commonly in the political realm and Afghan national politics often are caricatured as interminable Pashtun tribal squabbling. ${ }^{1}$ The primary problem with that framework is conceptually internal, by which I mean the relationships in and between the tribal, ethnic and national layers of Pashtun identities are not addressed. A secondary structural defect of the Pashtun domination thesis involves what might be called its external relations. The specific problem here is another prominent discursive pillar of academic and official understandings of Afghanistan with which the Pashtun domination thesis often is paired, namely, the failed state framework of reasoning. It is hard to understand how something that is failed dominates

Correspondence Address: Shah Mahmoud Hanifi, James Madison University, Harrisonburg, VA, USA. Email: hanifism@gmail.com

${ }^{1}$ See, for example, L. Poullada (1970) The Pashtun Role in the Afghan Political System (New York: The Afghanistan Council of the Asia Society); and A. Hyman (2002) Nationalism in Afghanistan, International Journal of Middle East Studies, 34, pp. 299-315.

(C) 2016 Editors of Middle East Critique 
anything else. The fundamental ill fit between the conceptual templates of domination and failure begets a number of separate inquiries and observations about state-society relations in Afghanistan and ways of 'knowing' the country.

A noticeable feature of most treatments of modern Afghanistan, particularly in writings produced before 2001, is a tendency to view the country as somehow removed from its surroundings. There is an important strand within the discourse of Afghanistan that renders it fundamentally if not naturally isolated, even xenophobic, with only episodic engagements and mainly inconsequential contacts with its neighbors and beyond. Not only is the country frequently said to be isolated from the world, it is not unusual for the villages of Afghanistan to be portrayed as separated from each other. ${ }^{2}$ Furthermore, Afghan cities typically are narrated as having little if any interaction with each other. Whether alleged or implied, the isolation of Afghanistan as a whole and of its parts, both internally and externally, accounts for the historical stasis that lies at the problematic core of the Pashtun domination thesis.

I am not questioning the existence of Pashtun tribalism, ethnicity or nationalism in Afghanistan or even outside the country. ${ }^{3}$ Rather, I am interested in how those features of Pashtun identity have come to be known and acted upon. It is striking that the treatment of these dimensions of Pashtun identity emerged and retained currency in the US academy without substantive ethnographic, historical or theoretical engagement of Pashtuns, especially articulations of tribalism, ethnicity and nationalism among them in Afghanistan. How academic discourse about Pashtuns in Afghanistan took shape is relevant because those problematic intellectual understandings were transferred wholesale into US intelligence agencies, foreign policy-making networks, and military institutions by well known agents, among whom Louis Dupree was and Thomas Gouttierre is the most publicly visible. ${ }^{4}$

Dupree was an archetypal synthesis of an American World War II military veteran who became a scholar and an influential state informant after the war. ${ }^{5}$ His career spanned the Cold War, and his writings and views significantly influenced how Washington dealt with Afghanistan, leading up to and most importantly after the December 1979 Soviet invasion.

${ }^{2}$ See, for example, L. Dupree (1989) The Inward Looking Society, in: L. Dupree (ed.) Afghanistan (Princeton, NJ: Princeton University Press), pp. 248-251.

${ }^{3}$ Treatment of Pashtuns and Pashto in Pakistan is beyond the scope of this article.

${ }^{4}$ On the role of Dupree see United States Congress (1989) A Tribute to the Late Dr. Louis Dupree. Available at http://www.jezail.org/02_essays/01fr_dupree.html, accessed October 28, 2015; on Gouttierre see Sourcewatch. org (nd) Tom Gouttierre. Available at http://www.sourcewatch.org/index.php?title=Tom_Gouttierre, accessed October 28, 2015.

${ }^{5}$ For more on the cooptation of American anthropology during World War II and the role of anthropology and anthropologists in contemporary US military operations, especially in the Human Terrain System, see D. H. Price (2008) Anthropological Intelligence: The Deployment and Neglect of American Anthropology in the Second World War (Durham: Duke University Press); idem (2009) Weaponizing Anthropology: Social Science in Service of the Militarized State (Oakland and Petrolia, CA: CounterPunch and AK Press); R. J. Gonzalez (2009) American Counterinsurgency: Human Science and the Human Terrain (Chicago, IL: Prickly Paradigm Press); and Network of Concerned Anthropologists (2009) The Counter-Counter Insurgency Field Manual: Or Notes on Demilitarizing American Society (Chicago: Prickly Paradigm Press). These authors are responding to numerous writings by D. Kilcullen, M. McFate and D. Petreaus including most importantly the revised Counterinsurgency Field Manual (The United States Army/Marine Corps (2007) Counterinsurgency Field Manual: U.S. Army Field Manual No. 3-24; Marine Corps Warfighting Publication No. 3-33.5 [Chicago, IL: University of Chicago Press]). Author's Note: This article was under review when the HTS officially was terminated in June 2015. See R. J. Gonzalez (2015) The Rise and Fall the Human Terrain System, CounterPunch. Available at: http://www.counterpunch.org/2015/06/29/the-rise-and-fall-of-the-human-terrain-system/ accessed November $27,2015$. 
His covert activities at this time are not fully known or understood, and may never be, but Dupree's influential publications reveal perhaps the greatest and most unfortunate irony of the Pashtun-centrism that characterized academic and governmental understandings of Afghanistan in the United States prior to 2001: Negligible engagement of Pashtun communities or the Pashto language by the very scholars and government policy makers responsible for creating and acting on 'official' knowledge about Pashtuns in Afghanistan.

In terms of intellectual progress after 2001, the surge in attention on Pashtuns and Pashto evident in the US academy and government, mainly as reified colonial British essentializations of Afghanistan, reproduced a colonial tendency to militarize and weaponize knowledge about other cultures. The challenges and failures of the international community evident in Afghanistan in no small measure are founded on the fragile intellectual architecture of nineteenth-century British colonial constructions of knowledge about Pashtuns. These understandings were institutionalized in US academia and incorporated into the US and other national and international policy-making machineries.

It is difficult not to wonder whether post-2001 developments in Afghanistan would have been different if the US academy, government and other global actors had been able to surmount the intellectual inheritance of colonialism regarding Pashto and Pashtuns and their cultural and historical locations in Afghanistan. For understandings of ethnicity generally and Pashtun ethnicity specifically, studies of Afghanistan are marked by a conspicuous avoidance of theories of ethnicity. One important theoretical paradigm that has not received attention is Fredrik Barth's work on ethnicity that is ethnographically grounded among Pashtuns. ${ }^{6}$ Barth's work has shortcomings, and it ought not be considered by any means as reflective of contemporary society among Pashtuns in Afghanistan, but it has inspired students and scholars from multiple disciplines working all over the world for roughly two generations.

Barth's ethnographic work among Pashtuns led to the emergence of a distinct 'Barthian' school of thought on how ethnic identity is expressed in multiethnic settings, and it has relevance for understanding Afghanistan. Barth views Pashtun identity as revolving around the situational expression of three core values: purdah or female seclusion; jirga or decision by council; and melmastia or hospitality. These three values can be construed as the basis of Pashtunwali or the code by which Pashtuns practice and therefore maintain their ethnic identity in polyethnic settings. The ethnographic basis of Barth's theorizing involves useful attention to use of the Pashto language as an important but not in itself sufficient trait to carry the weight of Pashtun ethnic identity.

Given the power, prominence, and salience of Barth's work on how Pashtun identity is demonstrated linguistically and through the expression of core values, it is astounding that those working on Afghanistan generally have not considered it, even if only to disagree with it. ${ }^{7}$ It is especially curious how state actors, especially the rulers in Afghanistan who comprise the most salient demographic element around which notions of Pashtun domination of Afghanistan are hinged, have not been exposed to applications or interrogations of Barth or any other scholarly approach to ethnic identity. Questions about how Afghan rulers linguistically practiced and culturally experienced Pashtun tribalism or ethnicity have not

\footnotetext{
${ }^{6}$ See F. Barth (1969) Ethnic Groups and Boundaries: The Social Organization of Cultural Difference (Boston, MA: Little Brown), particularly the Introduction, pp. 9-38 and Pathan Identity and its Maintenance, pp. 117-134.

${ }^{7}$ Barth's work on political leadership in Afghanistan (not Pashtun ethnicity) is treated in D. B. Edwards (1998) Learning from the Swat Pathans: Political Leadership in Afghanistan, 1978-97, American Ethnologist, 25, 4, pp. 712-728.
} 
been asked let alone pursued in the literature about the Afghan state, which is portrayed as designed exclusively to service Pashtuns and their ethnic domination agenda. The absence of attention to the Pashtun cultural substance of Afghan state rulers is glaring because of how the Pashtun identity of the Afghan state has been so thoroughly inscribed without having been described beyond a rudimentary set of anecdotes, clichés and unsubstantiated claims that at a rare best render Pashtun-ness invisible and in the more common worst-case scenario trivialize and misrepresent Pashtuns and their perspectives.

Ultimately, the discrepancy between the experience of being a Pashtun and what Pashtuns are represented to be is founded on the general absence of Pashtun voices in the literature about them. The voiceless-ness of Pashtuns is created and sustained by highly militarized and politicized agendas routed through the Afghan state that target them as an enemy to be physically exterminated and culturally eradicated. ${ }^{8}$ In other words, there are local and global agencies with vested interests in muting the voices of Pashtuns in Afghanistan, just as there are jailhouse and courtroom agencies that keep voices of the wrongfully imprisoned from being heard.

The state, of course, includes more than just rulers, as it also encompasses institutions. When one begins to examine the history of schools, courts and the bureaucracy more generally, the Afghan state appears to be even more thoroughly dominated by the Persian language and Persian elements, which can be viewed as subordinating the Pashto language and Pashto-based interest groups. To anticipate a logical line of inquiry, yes, the Afghan military, surely more than any other state institution, has incorporated Pashto and Pashtuns. However, a military presence does mean dominance and more importantly, there is a very prominent strand of Afghan state history that involves military campaigns directed against Pashtun populations. In fact, the greatest historical resistance to the Afghan state has emanated among its constituent Pashtun populations.

Once liberated from the shackles of an unsubstantiated thesis of ethnic domination, the available evidence can be revisited thereby opening other lines of inquiry about ethnic relations and the power bases of the Afghan state. One important historical location for such reinterpretation concerns the experience of the Shi' a Hazara community during the reign of Abd al-Rahman (r. 1880-1901), who widely and correctly is understood to have been at the apex of Sunni Afghan state power when modern Afghanistan emerged at the end of the nineteenth century. Abd al-Rahman's conquest of the Hazarajat was brutal and involved the use of Pashtun troops. For our purpose the salience of this violent episode is that it is cited as the basis of ongoing 'ethnic hostility' between Hazaras and Pashtuns throughout and indeed outside of Afghanistan and as the prototype example of Pashtun ethnic oppression. However, what I suggest is that Abd al-Rahman's conquest of the Hazarajat can be viewed as a process that is more typical of state expansion than ethnic oppression. More than just a possibility, it is quite probable that beyond mere political economy, any cultural bigotry involved in the Afghan state's conquest of the Hazarajat involved Islam in far more important ways than the subsidiary and misconstrued issue of Pashtun ethnic dominance. ${ }^{9}$

\footnotetext{
${ }^{8}$ One exception to the generalized silence of Afghan voices in the discourse of Afghanistan is found in A. Daulatzai (2006) Acknowledging Afghanistan: Notes and Queries on an Occupation, Cultural Dynamics, 18(3), pp. 293-311.

${ }^{9}$ It is important to note that the Afghan ruler Habibullah (r. 1901-1919) appointed a Hazara historian to write the official state history of his father Abd al-Rahman's reign. See R. D. McChesney \& M. Khorammi (2016) The History of Afghanistan: Fayz Muhammad Katib Hazarah's Siraj al-tawarikh, 4 vols. (Leiden \& Boston: Brill).
} 


\section{New Ways of Knowing the Country: Analytical Reorientation around Migration and Persianate Themes}

To be conscious of how the Pashtun domination thesis and state failure paradigm combine to limit the scope of understanding Afghanistan is to free oneself from the tautological reasoning about the country that traps one into believing Pashtuns are somehow exclusively responsible simultaneously for making and breaking the state because of their ethnicity. It is surely possible to reckon with the Afghan state and its rulers in ways that transcend intellectually hollow and politically counterproductive Pashtun ethnic stigmata. I argue that, in order for the country to survive, it is absolutely necessary to do so. What ordinarily is thought of as Afghanistan has a very deep historical timeline but the historiography of Afghanistan is quite shallow. Recognizing that the designation 'Afghanistan' assumed currency gradually over the course of the nineteenth century, OCLC WorldCat searches indicate extremely large increases (nearly doubling) in the amount of available literature about the country around the dates of international military action in the country $(1839-42,1878-80,1919,1979,2001)$. The surges in literature around the years of war in Afghanistan involve greatly increased numbers of writings about the wars themselves, which serve to narrow further an already shallow pool of writings. The academic literature about Afghanistan appears particularly scarce both in volume and variety when compared with the exponentially larger amount of scholarship on India and Iran that combine to provide a number of more intellectually robust treatments of ethnicity, tribalism and nationalism than what animates the increasingly militarized discourse on Afghanistan.

Pashtuns are at the historical core of how Afghanistan is understood and historically a core component of Pashtun identity is nomadism. Over the long term multiple permutations of nomadism and different types of sedentarization processes that can recycle 'back to new' forms of nomadism are evident among Pashtun communities both within and beyond the boundaries of Afghanistan. Migration comes into analytical play prominently for Pashtuns, and in terms of Afghanistan, at least six varieties of migration can be identified. By preposition these six varieties are: in, out, to, through, internal and return migration/s. ${ }^{10} \mathrm{~A}$ research team would be required to understand adequately how these forms of migration figure within the histories of the diverse communities of Pashtuns and the multiple other ethnic groups that are found inside and outside of Afghanistan today. Cursory reflection about this complexity destabilizes the highly politicized 'actionable' understandings of all ethnic groups in the analytical arena of Afghanistan as being geographically isolated, historically stable, or socially homogenous. To the detriment of all involved, these notions of isolation, stasis and similitude are regularly synthesized to generate Orientalized caricatures and stereotypes of Pashtun communities.

To dismantle prevailing notions of timelessness among Pashtuns one must deal with the deep past. Doing so using migration as an analytical variable reveals that the combined histories of many forms of migration account for the ethnic complexity, which is in turn used to characterize contemporary Afghanistan. A general chronology can begin with the migrations of Aryan populations from the north that are dated within the second millennium BCE. ${ }^{11}$ These migrations are cited to explain the long-term presence of Indo-European

\footnotetext{
${ }^{10}$ A seventh form, circular migration, is addressed below. An excellent example of migration-centered analysis is A. Mondsutti (2005) War and Migration: Social Networks and Economic Strategies of the Hazaras of Afghanistan (London: Routledge).

${ }^{11}$ The following narrative of the pre-1500 CE period generally follows W. Ball (2008) The Monuments of Afghanistan: History, Archaeology and Architecture (London: I. B. Tauris), pp. 40-99.
} 
languages in the country. From the west in the fifth century BCE, the Persian kings Cyrus and Darius incorporated Afghanistan into their Achaemenian Empire. In the third century BCE, Alexander the Great conquered the Achaemenian lands and resettled Greeks and Macedonians in the Kabul Valley and in the northern region known then as Bactria and today as Balkh. Later Greek geographers such as Eratosthenes (276 BCE-195 BCE) and Strabo (64 BCE-23 CE) located the region of Ariana in the south of contemporary Afghanistan.

Migrations into what became Afghanistan came from the north and west episodically over two millennia before Alexander's presence. For approximately a millennium after Alexander, there were influential movements of people and ideas through the country from the east and south. The first of the migrations from the Indian subcontinent involved the Mauryan dynasty (322 BCE-185 BCE). The founder of the Mauryan Empire was Chandragupta (r. 322-298 BCE). His grandson Ashoka (r. 273-232 BCE) renounced violence and adopted Buddhism. Ashoka is responsible for an important rock edict written in Greek and Aramaic extolling the virtues of his new faith, which was unearthed in Qandahar in the middle of the twentieth century CE.

The next major Indian presence is the Gandhara civilization, which was centered in the Peshawar valley. Although Gandharan culture has been defined and dated in a variety of sometimes incompatible ways, for present purposes it is sufficient to note that it lasted from roughly 100 to $600 \mathrm{CE}$ and combined the in-migration of Kushan Buddhists from the east that overlaid the Mauryan and other later- and post-Vedic world views. Buddhism from east and south Asia combined with a version of Bactrian Hellenism composed of Greek, Macedonian, Persian and local elements to give Gandharan culture and civilization its eclectic and synthetic characteristics. The version of Buddhism that emerged in Bamiyan in the sixth century CE was distinct from that of Gandhara due in part due to a different combination of historical ingredients. Most notable among these was a historical layer of Turkish and Inner Asian in-migrations beginning in the second century CE, including the Scythians, the Kushans (most notably Kanishka [r. 127-151 CE]), and Hepthalites or White Huns.

Islam first appeared in the region in the seventh century via the Indian Ocean, Sindh Province and the Indus River. However, a durable Islamic state presence was not established in 'Afghanistan' until the tenth century, when the Ghaznavi Empire (963-1187) ruled in eastern Afghanistan. The Ghaznavis displaced the Hindu Shahi dynasty that was based in Kabul and had exhibited a synthesis of Hindu, Buddhist and Turkic elements. The Ghori Empire (1148-1215) succeeded the Ghaznavis and was based in the central west of the country. Therefore, prior to the permanent arrival of Islam the area now known as Afghanistan experienced substantial historical layers of in-migration over approximately 2,000 years from the north (Aryan and Turkic peoples), west (Persian and Mediterranean peoples), and east/southeast (Buddhist and Hindu peoples). Islam's lasting presence was the result of in-migrations of Turkic groups from Central Asia. More importantly, an Islamic state presence in the Hindu Kush initiated a relatively continuous series of through-migrations of Persian and Turkic peoples. Of most relevance are the successive out-migrations of local populations identified as Afghans to the plains of north India and South Asia more broadly.

With the Ghaznavis a new series of migrations inspired by Islamization potentialities in Hindustan came full circle so to speak. For just as Islam first appeared in the region via the Indian Ocean roughly three centuries earlier, the growing presence of Islam in medieval India meant an increasing exposure of Afghans and 'Afghanistan' to the global world of Indian Ocean commercial networks that connected South Asia with the Persian Gulf and therefore the Arab world, a zone that also was encountered via the Red Sea. Through increasingly dense nets of overland and aquatic commercial routes, proto-Afghanistan was demographically 
and economically reconfigured in significant ways by the arrival and increasing influence of Islam.

Islamic polities, like many other forms of state organization, are heavily urban-based entities. A collective urban history of Herat, Kabul, Mazar-e Sharif and Qandahar in Afghanistan has not been written, but one notable feature of the Islamic reconfiguration of 'Afghan cities' through new patterns of migration to and between them deserves attention. That is the separation between Kabul, which appears anchored in a way that points North to an archaic trans-Eurasian global Silk Road heritage, and Qandahar, that seems awakened by Islam from an ancient commercial slumber to look progressively South to the expanding Indian Ocean trade networks that were also inter-continental and global, just differently so. The fracturing of relations between Kabul and Qandahar through the arrival of Islam reflects a distinction described over 1,000 years previously by Eratosthenes and Strabo, the Greek polymath Geographers and Philosophers who separated what is now Afghanistan between Bactria in the north and Ariana in the south.

The polarity between Kabul and Qandahar productively viewed in light of differential global commercial circuitry, and the contest over the two cities is well illuminated by the competing interests of the Mughal (1526-1858) and Safavi (1501-1722) Empires. The Mughals and Safavis dueled over the two cities regularly for approximately two centuries, a contest that increased the social and economic distances between them during the early modern era. In this period Kabul and Qandahar should be viewed not only in relation to each other but also in relation to Delhi and Isfahan, and Bukhara and Bombay, at the very least. ${ }^{12}$ It was in the context of the Mughal Empire in the late sixteenth century that the Pashto language became textualized. Early Pashto writings exhibit a significant influence of Persian literary forms and vocabulary, as well as large numbers of Indian and Turkish loanwords. There is an important distinction between Pashto's incorporation of Persian elements and Indian elements, the former being essentially grafted unaltered and the latter more organically ingested and transformed. ${ }^{13}$ By the late eighteenth century when the British had supplanted the Mughals in South Asia and the Afghan Empire had emerged under Ahmad Shah Abdali/ Durrani (r. 1747-1773), there was a growing market for Pashto language writings, and a distinct Pashtun identity had become an established fact. We are on firm historical ground in viewing Pashtun ethnogenesis as a Mughal period phenomenon, and it is clear that Pashtun identity emerged either from within or alongside the Afghan identity category that had been in place since approximately $1000 \mathrm{CE}$, at least in written form.

Both of these identities, Afghan and Pashtun, historically and culturally are grounded in a Persian cultural template. Beyond this shared Persianate heritage, both communities have incorporated Turkish linguistic elements and features of social organization, such as political hierarchies including the concept of khan that was likely imported during the thirteenth century period of Mongol prominence through Eurasia. The thirteenth century

\footnotetext{
${ }^{12}$ See N. Steensgard (1999) The Route Through Qandahar: The Significance of Overland Trade between India and the West in the Seventeenth Century, in S. Chaudhury \& M. Morineau (eds) Merchants, Companies, and Trade: Europe and Asia in the Early Modern Era (Cambridge: Cambridge University Press), pp. 55-73.

${ }^{13}$ See V. Kushev (1997) Areal Lexical Contacts of the Afghan (Pashto) Language (Based on the Texts of the XVIXVIII Centuries), Iran \& the Caucasus, 1, pp. 159-166; V. Kushev (2001) The Dawn of Pashtun Linguistics: Early Grammatical and Lexicographical Works and Their Manuscripts, Mansuscripta Orientalia, 7 (2), pp. 3-9; and S. Mahmoud Hanifi (2013) A History of Linguistic Boundary Crossing Within and Around Pashto, in: M. Marsden \& B. Hopkins (eds), Beyond Swat: History, Society and Economy along the Afghanistan-Pakistan Frontier (London: Hurst \& Co. and New York: Columbia University Press), pp. 63-76.
} 
in South Asia marks the beginning of a critical 300-year period of Turkish and Afghan rule over north India that is known as the Delhi Sultanate (1206-1526). ${ }^{14}$ It was the Delhi Sultanate system that Babur supplanted to found the Mughal Empire. We must recall that Babur, a Turk genealogically connected to Chengiz Khan and Timur, incorporated some Afghans and Pashtuns and defeated others while gaining his reputation in the Kabul region before conquering Delhi and establishing the Mughal empire. ${ }^{15}$ There was a relatively continuous flow of Afghan and Pashtun communities into Hindustan from the establishment of the Delhi Sultanate in 1206 and the British assumption of the right to collect the revenue of the lucrative semi-independent Mughal province of Bengal in 1765. Large numbers of these Afghans and Pashtuns settled in small towns and villages in the Himalayan foothills. ${ }^{16}$

Clearly, some of these Afghans in India were speakers of Pashto and it is equally clear that large numbers of originally Pashto-speaking communities stopped speaking Pashto once settled in locations such as Dehra Dun and Rohilkhand. The important point to emphasize is this: Some Afghan and Pashtun diaspora communities living in north India self-identified - and also were identified by others as Pathans. We must appreciate that when the British began to reckon with the social landscape of India for administrative purposes they encountered a historically complex and layered mix of recent immigrants and long-established communities of Afghans, Pashtuns and Pathans. There would have been no clear rule separating the terms or their referents during this period when there was inter-mixture of the labels for both ordinary and strategic reasons. Most members of these communities would have been familiar with an Indian language and would have spoken or claimed their ancestors previously spoke Persian and a lesser number of whom would have spoken or claimed their ancestors previously spoke Pashto in addition to Persian.

First through a scribal army and then through industrial printing, colonial authorities produced linguistic and village surveys, district and provincial gazetteers, censuses and maps that pervaded and textually animated the bureaucracy, army, education and legal systems of their empire more broadly. Through a sea of paper the British colonial regime ultimately convoluted rather that clarified the three categories of Afghan, Pashtun, and Pathan that arose in different ways and at different times in the Mughal and pre-Mughal periods. ${ }^{17}$ The result today is that scholars and actors absorbing these labels are subject to and reproduce the pre-colonial vagueness and metonymy between these terms that were amplified and institutionalized during the colonial period. ${ }^{18}$

\footnotetext{
${ }^{14}$ See W. Haig (1928) The Cambridge History of India, vol. 3, Turks and Afghans (New York: Macmillan and Cambridge: Cambridge University Press); and A. Wink (2002 [1991 and 1997]) Al-Hind: The Making of the Indo Islamic World, 2 vols. (Leiden: E. J. Brill).

${ }^{15}$ It should be noted that Babur so enjoyed Kabul and its geographic and social setting that he requested to be buried there. For Babur's description of Kabul see Z. Muhammad Babur (1993) Baburnama, Part Two: Kabul (Cambridge: Harvard University Press).

${ }^{16}$ For more on these migrations and settlements, see J. J. L. Gommans (1995) The Rise of the Indo-Afghan Empire, c. 1710-1780 (Leiden: E. J. Brill). For consideration of some of the texts produced by these Afghans in India about their own histories, see N. Green (2008) Tribe, Diaspora, and Sainthood in Afghan History, The Journal of Asian Studies, 67(1), pp. 171-211.

${ }^{17}$ Which in some ways runs counter to Anderson's argument about the colonial state creating exclusive identities for is subjects, for which see B. Anderson (1991) Imagined Communities: Reflections and the Origin and Spread of Nationalism (London: Verso).

${ }^{18}$ Charles Lindholm \& Fredrik Barth are two important examples of careful, distinguished scholars whose very useful work is diminished by uncritically lumping the three terms together. See C. Lindholm (1980) Images of the Pathan: The Usefulness of Colonial Ethnography, Archives Europeennes de Sociologie, 21(2), pp. 350-361; and F. Barth Pathan Identity and its Maintenance, in: Ethnic Groups and Boundaries.
} 
An important distinction exists between the smaller towns and villages in north India known as qasbahs and where the majority of Pashto speakers were found, and the major cities of Hindustan such as Delhi and Lahore where Persian more commonly was used. ${ }^{19}$ An urban Persian-rural Pashto polarity took shape in India before the rise of the Afghan empire and the roughly simultaneous onset of British rule in India. That divide to some extent is a false one because Persian certainly was used in the rural zone and Pashto speakers could be found in most Indian cities. For heuristic purposes, however, there is a very useful distinction to be made between cities and the states that took shape around them wherein Persian was the common language of bureaucracy, administration and urban society on the one hand, and a rural zone where Pashto among other languages was more ordinarily found, on the other hand.

Embryonic Afghanistan gestated in fluid relations between the Mughal and Safavi empires that ebbed and flowed over the fates of Kabul and Qandahar. The Afghan empire that arose in the eighteenth century out of those regional imperial imperatives must be distinguished from the Afghan state that took shape in the nineteenth century in the context of Britain's global imperial project. The first period can be understood through the migratory history of Ahmad Shah who was born in 1722 in the Mughal district of Multan, but raised in the eastern Safavi provinces where he entered the service of arguably the last of the great nomadic world conquerors, Nadir Shah Afshar (r. 1736-1747). Ahmad Shah's empire was similar to Nadir Shah's empire in respect to hostilities against Ghalzay Pashtuns and invasions of India. ${ }^{20}$

Ahmad Shah's official history and known correspondence are written in Persian, and his biography and empire involve important roles for Shi' ism and Sufism. There is a compendium of Pashto poetry ascribed to Ahmad Shah. His Pashto poetry is unremarkable, except for one often-cited couplet about forgetting the Delhi throne for thoughts of the mountains of Pakhtunkhwa. Beyond those two lines, Ahmad Shah's Pashto poetry does not extol the virtues of Pashtun identity such as did other authors, including Khushhal Khan Khattak (1613-1689) in their writings. That he commissioned a teaching and conversation manual to help his son learn Pashto prompts questions as to whether Ahmad Shah personally could have been responsible for authoring the Pashto poetry ascribed to him. ${ }^{21}$ The key point is that a small bit of poetry should not be interpreted as a cornerstone cultural credential sufficient to account for Ahmad Shah's 'unification of the Pashtun tribes to form the Afghan state,' as the mantra is now recited. Ahmad Shah's name change from Abdali to Durrani raises more questions than answers about Pashtun and other interactive identities such as Sufism that were involved in Afghan state formation. ${ }^{22}$

\footnotetext{
${ }^{19}$ For qasbahs see C. A. Bayly (1988) Rulers, Townsmen and Bazaars: North Indian Society in the Age of British Expansion, 1770-1870 (Cambridge: Cambridge University Press).

${ }^{20}$ For the Abdalis see C. Noelle (2010) The Abdali Pashtuns Between Multan, Qandahar and Herat, in: M. Marsden \& B. Hopkins (eds) Beyond Swat: History, Society, and Economy along the Afghanistan-Pakistan Frontier (London: Hurst \& Co. and New York: Columbia University Press), pp. 31-38. On Nadir Shah Afshar, see L. Lockhart (1993 [1938]) Nadir Shah: A Critical Study Based Mainly upon Contemporary Sources (Jalandhar, India: Asian Publishers). For the Ghalzays, see L. Lockhart (1958) The Fall of the Safavi Dynasty and the Afghan Occupation of Persia (Cambridge: Cambridge University Press). For Ahmad Shah Durrani, see G. Singh (1981 [1959]) Ahmad Shah Durrani: Father of Modern Afghanistan (Lahore: Tariq Publications).

${ }^{21}$ For Ahmad's Shah's commissioning of Mulla Pir Muhammad Kakar to prepare the Marifat al-Afghani (written in approximately 1773) for his son, Sulayman, see V. Kushev (2001) The Dawn of Pashtun Linguistics.

${ }^{22}$ For more on the importance of re-reading Ahmad Shah's biography, see S. M. Hanifi (2012) Quandaries of the Afghan Nation, in: S. Bashir \& R. D. Crews (eds) Under the Drones: Modern Lives in the Afghanistan-Pakistan Borderlands (Cambridge, MA: Harvard University Press), pp. 83-101.
} 
To reiterate the substance of an earlier point, the making of the modern Afghan state that occurred under Abd al-Rahman at the end of the nineteenth century should not be understood as another expression of Pashtun domination. As with Ahmad Shah, there is scant evidence of Abd al-Rahman speaking Pashto or invoking Pashtun tribal values or practicing Pashtunwali. With the support of his British colonial patrons he substantially enlarged and transformed the state structure he inherited. Abd al-Rahman continued the practice established by Ahmad Shah of relying on Persian language resources that grew more entrenched at the bureaucratic and cultural core of his authoritarian regime. Abd al-Rahaman's 'internal colonial' conquests targeted Pashtun and non-Pashtuns alike. Abd al-Rahman's political agenda was animated by Islam and fueled by colonial resources. ${ }^{23}$

It is possible to identify attempts to harness Pashto language resources and assertions of Pashtun identity in the context of the Afghan state institutions during the twentieth century. One finds expressions of Pashto in the army, schools and in emerging reading publics formed around newspapers, and the publications of literary and historical societies in urban centers, mainly Kabul, and speaking publics organized around oral poetry readings and competitions in the rural zone, particularly in the east. ${ }^{24}$ We must move beyond the tendency to view the rural zone as an exclusively oral domain pitted against the written words of fully literate and textually urbanites, but a centuries old division between Persianate cities and rural Pashtuns is apparent to a certain degree. The summary point to be made for our purposes applies to the nature of the state: The forms of Pashto language use and Pashtun identity expression combined to reveal that state norms and structures were dominated, ironical it may seem to some, by Persian language resources and networks against and from within which Pashto and Pashtuns struggled for recognition and support.

This conclusion does not preclude the possibility of identifying Pashtun elites who consciously and publicly used the Pashto language in spoken and written form and who maintained Pashtun tribal ties. The idea of urban Pashtuns is replete with contradictions in the first instance, and if such urban Pashtun elites existed, there is very limited data about them. Granting the possible exceptional presence of a small group of Pashtun elites despite the Afghan state's cultural orientation, these Pashtun individuals stand out as exceptions in the crowds of non-Pashtun Persian speakers among whom large numbers of Shia Qizilbash and Sayyids are particularly evident, which in turn explains why Pashtun-centered initiatives generally have not been sustained or successful. Therefore, the essence of Pashtun visibility in the Afghan state structure is how exceptional and grafted rather than how ordinary and organic it appears. The Loya Jergas of the twentieth and twenty-first centuries are primary examples of the Afghan state's episodic and unsuccessful attempts to harness the illusion of Pashtun identity in a bid to impose its colonially constructed political power over Afghan society. ${ }^{25}$

\footnotetext{
${ }^{23}$ S. M. Hanifi (2008 [2011]) Connecting Histories in Afghanistan: Market Relations and State Formation on a Colonial Frontier (Stanford, CA: Stanford University Press), pp. 97-164.

${ }^{24}$ For more on Pashto orality and publics, see J. Caron (2011) Reading the Power of Printed Orality in Afghanistan: Popular Pashto Literature as Historical Evidence and Public Intervention, The Journal of Social History, 45(1), pp. 172-194; and J. Caron (Forthcoming) Social Inequality and Ideological Circulation in Eastern Afghanistan, 1930-1960: Oral Publics for and against the Patriarchal State, in: S. Mahmoud Hanifi (ed.) Power Hierarchies and Hegemony in Afghanistan: State Building, Ethnic Minorities, and Identity in Central Asia (Forthcoming, London: I. B. Tauris).

${ }^{25}$ M. Jamil Hanifi (2004) Editing the Past: Colonial Production of Hegemony Through the 'Loya Jerga' in Afghanistan, Iranian Studies, 37(2), pp. 295-322.
} 
The economic dimensions of Afghanistan's colonial architecture resulted in the country's impoverishment and marginalization in the context of the nineteenth-century global economy. ${ }^{26}$ While Indian and global imperial economics certainly informed British political calculations in relation to Afghanistan, it is the intellectual architecture of colonialism in Afghanistan that requires attention. In other words, by colonialism in Afghanistan I mean here the effects of colonialism on how British authorities thought about Afghanistan. Understandings of Afghanistan frame actions toward it and the British colonial understanding of Afghanistan took shape around the reports and ultimately the publication of a book written by Mounstuart Elphinstone who led the first British delegation in 1808 to the court of the Durrani ruler Shah Shuja. Elphinstone's An Account of the Kingdom of Caubul (1815) set the parameters for how Afghanistan came to be known in British India. ${ }^{27}$ Colonial knowledge formations are geared for political utility. Similar to other forms of knowledge, colonialism generated some new and important lines of inquiry, in historical linguistics for example. However, because of the political expediencies demanded of colonialism, it tends to be built on simplifications and limited, sometimes inconsistent and contradictory data.

Elphinstone's work made the point that his Durrani host, as a grandson of Ahmad Shah, was from an entitled lineage, but he also indicates that Shah Shuja was not a Pashto speaker. ${ }^{28}$ The exposure to Pathan communities in India where Pashto was receding in use likely informed Elphinstone's thinking, but the point of emphasis is that his authoritative statements legitimized 'Pashtun' rulers of Kabul who did not speak Pashto. In terms of British colonial knowledge formations about Afghanistan, this framework of understanding simultaneously elevated and devalued the place of Pashto in the Afghan state structure. A primary affect of this structural contradiction was that colonial officials did not need to know Pashto in order to interact with Afghan elites. The contrasting competencies and career trajectories of Henry George Raverty and Henry Walter Bellew in the second half of the eighteenth century reveal how the study of Pashto was confined to the military exam system where it was subject to simplification and modification in accordance with increasingly official and standardized Hindustani language formats. ${ }^{29}$

As indicated by the title, Elphinstone's book also enshrined a Kabul-centric view of Afghanistan. The map accompanying the book elevates Kabul at the expense of Afghanistan that as an idea appears very much in the background. Elphinstone first etched upon the tabula rasa of the colonial imagination a Persianized ruler of Kabul who inherently would be the ruler of Afghanistan. The Afghan ruler of Kabul did not need to speak Pashto or demonstrate Pashtun tribal connections, he only needed to know how to manipulate Pashtun identity to extort consent from subjugated populations and market his legitimacy to increasingly powerful external actors. The tendencies toward repetition and redundancy within the colonial bureaucracy gave Elphinstone's first words about proto-Afghanistan's political system and

\footnotetext{
${ }^{26}$ See S. M. Hanifi, Connecting Histories in Afghanistan, pp. 97-164.

${ }^{27}$ See M. Elphinstone (1992 [1815]) An Account of the Kingdom of Caubul, and Its Dependencies in Persia, Tartary, and India, 2 vols. (Karachi: Indus Publications); and B. D. Hopkins (2008) The Making of Modern Afghanistan (London: Palgrave Macmillan), especially 'The Power of Colonial Knowledge, pp. 11-33.

${ }^{28}$ S. M. Hanifi (2015) A Sampling of the Silences and Emphases in Mountstuart Elphinstone's Journey to Peshawar and An Account of the Kingdom of Caubul. Paper presented at the University of London School of Oriental and African Studies conference, Mountstuart Elphinstone and the Historical Foundations of Afghanistan Studies: Reframing Colonial Knowledge of the Indo-Persian World in the Post-Colonial Era, November.

${ }^{29}$ S. M. Hanifi (2011) Henry George Raverty and the Colonial Marketing of Pashto, in C. Talbot (ed.) Knowing India: Colonial and Modern Constructions of the Past (New Delhi: Yoda Press), pp. 84-107.
} 
social fabric lasting impact in the British imperial mindset and in the maze of colonial bureaucracies and institutions that formed a grid of control in India. How colonial ideas about the country were transferred to Afghans brings us back to the concept of migration, in this case a version that can be called circular migration. I argue circular migration is a far more accurate and effective model for understanding the history of state elites in Afghanistan than Pashtun domination.

Ahmad Shah followed a well-established historical pattern through the regularity of his eight incursions into India over the course of 20 years between 1747 and 1766. Another expression of a larger pattern of repeat or circular migration of Afghan elites begins with the encounter between Elphinstone and Shuja. Due to losing control of Kabul to his halfbrother Shah Mahmud, Shuja and his court followed Elphinstone out of their meeting point in Peshawar literally hours after signing the treaty the British sought to extract from the ruler of Kabul on April 14, 1809. Elphinstone knew he was signing a treaty with a ruler who soon would be deposed. Shuja spent a handful of years on the run in Kashmir and in captivity with Ranjit Singh before receiving a British pension and residence in Ludiana in the Punjab in $1816 .{ }^{30}$ With the exception of a failed bid to recover Kabul in 1832-1834, Shuja remained in Ludiana until being repatriated rather forcibly by the occupation Army of the Indus in 1839. In the context of their first occupation the British re-installed Shuja and also accepted the submission of the ruler they displaced in Kabul, Dost Mohammad (r. 1819-1839 and 1842-1863). Similar to Shuja after his first ouster, Dost went on to assume a British pension in India before colonial authorities facilitated his return to Kabul as ruler in 1842. Dost Muhammad began to receive a British colonial subsidy to bolster his rule in Kabul and to help guard Herat from perceived Iranian and Russian intrigues in the area in 1856.

It is important to consider the experiences of Ahmad Shah, Shah Shuja and Dost Mohammad already addressed together with similar experiences of Abd al-Rahman in Russian Central Asia (1868-1879), Nadir Shah (r. 1929-1933) born in British India (1883 Dehra Dun) and repatriated with British support, and the biographies of Amanullah (r. 1919-1929), Zahir Shah (r. 1933-1973), Najibullah (r. 1987-1992), and the more well-known Hamed Karzai (r. 2001-2014) and Ashraf Ghani (2014-present). In reviewing the history of Afghanistan, a basic pattern emerges: Rulers take local power in relation to external resources, which prompts the voluntary or forced migration of local political opponents, many of whom receive refuge and asylum from (perhaps the same) external powers that routinely provide resources to exiles. To complete one phase of a repeating pattern, a collusion of interests between powerful 'host' external actors who want to advance their peripheral interests combine with those of the deracinated dependent ex-elite 'guests' to facilitate the repatriation of diaspora elites.

This migration-based model neither privileges internal variables nor denies external influences. Rather, it is predicated on circulation and identifies a continual relationship between internal and external processes that form the Afghan political system. If accepted in rudimentary form and then used as a window to view the history of this region since the rise of Islam, the circular migration model of Afghanistan's political history carries a number of problematic implications for established understandings of the country. One notable concept that is destabilized by the circular migration model is that of two 'diaspora populations' of

\footnotetext{
${ }^{30}$ For more on Shuja's experiences in Ludiana, see S. M. Hanifi (2012) Shah Shuja's 'Hidden History' and its Implications for the Historiography of Afghanistan, South Asian Multidisciplinary Academic Journal. Available at http://samaj.revues.org/3384\#entries; accessed October 28, 2015.
} 
Afghans residing in India and Indians residing in Afghanistan that become less analytically distinct when multiple subsets of Afghans and Indians are viewed as circulating between 'home' and 'host' settings. ${ }^{31}$ The circular migration model also illuminates the cavernous dependencies on external resources that surely help elites consolidate local power but also surely destabilizes the legitimacy of these externally dependent elites in the eyes and minds of local populations irrespective of ethnicity.

To understand Afghanistan more fully and properly, we need to re-imagine its long-term history creatively and to redeploy new meanings for the very old, distinct and overlapping historical geographies of Afghan and Pashtun populations inside and outside of the country itself. The consciously revisionist circular migration model helps to explain how Afghan elites were exposed to colonial frameworks of understanding and acting on Afghanistan while in 'diaspora' during which time they received training and incentives to transfer colonial practices and frames of reference to and through their 'own' country when 'repatriated.' The Afghan national reproduction of colonial categories and policies occurred through the agency of political elites who acquired a sense of self from the Other.

The Afghan elites' colonially inspired views of themselves and the society they dominated-largely by manipulating claims to Pashtun identity and limiting historically open-access to the world through various forms of migration-were 're-gifted' back to a variety of international actors during the twentieth century. These include a large number of French, German, Italian, Japanese, and most importantly for us Russian and American individuals, many of whom led Afghan state-sanctioned research teams that typically focused on archaeology and were funded by these foreign actors and their governments.

As noted above, Louis Dupree was the American archaeologist who first dealt with Afghan political elites in Kabul in the 1950s. Dupree adopted his local contacts' world views, and then through publications, private and secret correspondence he routed those views for circulation within the many networks of influential associates he maintained across the public, private, and state intelligence communities in the United States and abroad. As a doctoral student in archaeology at Harvard University, Dupree studied under Carleton Coon and Ernest Hooten whose combined ideas on race drew considerable attention and controversy. ${ }^{32}$ Dupree helped to fashion a racial and genetically-based understanding of ethnicity for Afghanistan at the expense of Barth's culture-based version of ethnicity.

Dupree was very influential in the US Fulbright and Peace Corps Programs in Afghanistan and his views were incorporated into the US academy and government through scores of American University Field Staff Reports that he authored from 1959 to $1980 .{ }^{33}$ Although trained as an archaeologist, the bulk of his writing and influence is not grounded in archaeology but rather on totalizing expertise. Dupree's career shift from a micro-specialist archaeologist to a macro-specialist jack-of-all-things-Afghan is worth noting, even if that aspect of his career cannot be pursued here. To examine more fully the circular migration model, one

\footnotetext{
${ }^{31}$ For attention to diaspora mercantile groups in global history, see P. D. Curtin (1996 [1984]) Cross-Cultural Trade in World History (Cambridge: Cambridge University Press); for attention to South Asian commercial diasporas in Central Asia and beyond, see S. C. Levi (2002) The Indian Diaspora in Central Asia and Its Trade, 1550-1900 (Leiden: Brill); and C. Markovits (2000) The Global World of Indian Merchants, 1750-1947: Traders of Sind from Bukhara to Panama (Cambridge: Cambridge University Press).

${ }^{32}$ S. M. Hanifi (2009) Comparing Regimes of Colonial Knowledge in Afghanistan, 1809-2009, lecture delivered at Stanford University's Center for Russian, East European and Eurasian Studies, April 2009.

${ }^{33}$ From the late 1950s until the early 1980s Dupree published scores of AUFS Reports on various subjects, with Afghan state policies, particularly in relation to international aid, domestic development and regional politics in South Asia during the Cold War, receiving primary consideration.
} 
would have to look carefully at the various networks that directly and indirectly channeled and facilitated the circulations of Afghans out of then back into Afghanistan, such as the Fulbright and Peace Corps programs, as well as the institutional nodes that sustained and structured those networks, including US universities such as the University of NebraskaOmaha, the University of Wyoming at Laramie, and Columbia University's Teacher College in New York City.

\section{Conclusion: Transcending Emotion}

Pashtuns need to be understood in terms of their own language and history, both of which are moving pictures so to speak, and in relation to the world around them that also is spinning. It is somehow disappointing to be saying basically that Pashto and Pashtuns have developed not in isolation from but in relation to other Indian, Persian and Turkish languages and communities and that they have been connected to the wider world for many centuries if not millennia and that colonial biases structured by military frames of reference have shaped the way Pashtuns are known and acted upon in the modern era. The disappointment is a reminder that more intellectual and less political reasoning is required for Pashtuns and Afghanistan.

I have strived to present evidence and counter arguments against a set of representations and understandings that mark the parameters for how Pashtuns are known and acted upon in the context of Afghanistan. This article is therefore one form of resistance to dominant colonial narratives about Pashtuns and imperial projects in Afghanistan that have been ethnicized to such an extent as to border on racism, a serious claim that will be emotionally difficult to digest for some Afghans and non-Afghans. Emotion perhaps also has been part of the problem here. It is odd to hear and read how much international love there is for Afghanistan given that conditions on the ground resemble an endless prison for local populations who beyond the growing ordinariness of military occupation are subject to panoptical surveillance blimps, drones, night vision devices, and bio-tracking technologies to monitor and control them. Love is to be sure an important emotion, but it can be full of contradictions and do considerable damage. Intense affairs of the heart, especially when doused in the illusory potions of exoticism and romanticism, tend to suspend objective thinking, which can lead to things going awry for the lover and the object of affection. ${ }^{34} \mathrm{I}$ suggest that Afghanistan can do without the love of the international community for a while because the consequences of the world's love for Afghanistan have become overwhelmingly negative for the vast majority of ordinary inhabitants of the country. Greater distance will do everyone some good. It will provide the time and space necessary to reconcile the dual colonially induced afflictions of Afghanophilia and Pashtophobia for which emotional and intellectual antidotes are urgently needed.

\section{Disclosure statement}

No potential conflict of interest was reported by the author.

\footnotetext{
${ }^{34}$ Orientalism, as described by E. Said (1994 [1979]) in Orientalism (New York: Vintage), is one manifestation of this condition. For repeated resorts to orientalist tendencies to exoticize, homogenize and romanticize Afghans by an established authority of the country, see, for example, N. Dupree (2002) Cultural Heritage and National Identity in Afghanistan, Third World Quarterly, 23(5), pp. 977-989.
} 


\section{References}

Anderson, B. (1991) Imagined Communities: Reflections and the Origin and Spread of Nationalism (London: Verso).

Babur, Z. M. (1993) Baburnama, Part Two: Kabul (Cambridge: Harvard University Press).

Ball, W. (2008) The Monuments of Afghanistan: History, Archaeology and Architecture (London: I. B. Tauris).

Barth, F. (1965 [1959]) Political Leadership among Swat Pathans (London: Althone Press).

Barth, F. (1969) Ethnic Groups and Boundaries: The Social Organization of Cultural Difference (Boston, MA: Little Brown).

Bayly, C. A. (1988) Rulers, Townsmen and Bazaars: North Indian Society in the Age of British Expansion, 17701870 (Cambridge: Cambridge University Press).

Caron, J. (2011) Reading the Power of Printed Orality in Afghanistan: Popular Pashto Literature as Historical Evidence and Public Intervention, Journal of Social History, 45(1), pp. 172-194.

Caron, J. (in press) Social Inequality and Ideological Circulation in Eastern Afghanistan, 1930-1960: Oral Publics for and against the Patriarchal State, in: Hanifi, S. M. (ed.) Power Hierarchies and Hegemony in Afghanistan: State Building, Ethnic Minorities, and Identity in Central Asia (London: I. B. Tauris).

Curtin, P. D. (1996 [1984]) Cross-Cultural Trade in World History (Cambridge: Cambridge University Press).

Daulatzai, A. (2006) Acknowledging Afghanistan: Notes and Queries on an Occupation, Cultural Dynamics, 18(3), pp. 293-311.

Dupree, L. (1989 [1973]) The Inward Looking Society, in: Dupree, L. (ed.) Afghanistan, pp. 248-251 (Princeton, NJ: Princeton University Press).

Dupree, N. (1993) Louis Dupree: An American Lover of Afghanistan, Central Asia, 33, pp. 119-130.

Dupree, N. (2002) Cultural Heritage and National Identity in Afghanistan, Third World Quarterly, 23(5), pp. 977-989.

Edwards, D. B. (1998) Learning From the Swat Pathans: Political Leadership in Afghanistan, 1978-97, American Ethnologist, 25(4), pp. 712-728.

Elphinstone, M. (1992 [1815]) An Account of the Kingdom of Caubul, and its Dependencies in Persia, Tartary, and India, 2 vols (Karachi: Indus Publications).

Gommans, J. J. L. (1995) The Rise of the Indo-Afghan Empire, c. 1710-1780 (Leiden: E. J. Brill).

Gonzalez, R. J. (2009) American Counterinsurgency: Human Science and the Human Terrain (Chicago, IL: Prickly Paradigm Press).

Gonzalez, R. J. (2015) The End of the Human Terrain System, in: CounterPunch, 29 June. Available at: http://www. counterpunch.org/2015/06/29/the-rise-and-fall-of-the-human-terrain-system/, accessed November 29, 2015.

Green, N. (2008) Tribe, Diaspora, and Sainthood in Afghan History, The Journal of Asian Studies, 67(1), pp. 171-211.

Haig, W. (1928) The Cambridge History of India, vol. 3, Turks and Afghans (New York, NY: Macmillan \& Cambridge: Cambridge University Press).

Hanifi, M. J. (2004) Editing the Past: Colonial Production of Hegemony Through the 'Loya Jerga' in Afghanistan, Iranian Studies, 37(2), pp. 295-322.

Hanifi, S. M. (2008 [2011]) Connecting Histories in Afghanistan: Market Relations and State Formation on a Colonial Frontier (Stanford, CA: Stanford University Press).

Hanifi, S. M. (2009) Comparing Regimes of Colonial Knowledge in Afghanistan, 1809-2009. Lecture delivered at Center for Russian, East European and Eurasian Studies (Stanford, CA: Stanford University).

Hanifi, S. M. (2011) Henry George Raverty and the Colonial Marketing of Pashto, in: Talbot, C. (ed.) Knowing India: Colonial and Modern Constructions of the Past, pp. 84-107. (New Delhi: Yoda Press).

Hanifi, S. M. (2012) Quandaries of the Afghan Nation, in: Bashir, S. \& Crews, R. D. (eds) Under the Drones: Modern Lives in the Afghanistan-Pakistan Borderlands, pp. 83-101. (Cambridge, MA: Harvard University Press).

S. M. Hanifi (2012) Shah Shuja's 'Hidden History' and its Implications for the Historiography of Afghanistan, South Asian Multidisciplinary Academic Journal. Available at: http://samaj.revues.org/3384\#entries, accessed October 28, 2015.

Hanifi, S. M. (2013) A History of Linguistic Boundary Crossing Within and Around Pashto, in: Marsden, M. \& Hopkins, B. (eds) Beyond Swat: History, Society and Economy along the Afghanistan-Pakistan Frontier, pp. 63-76 (London: Hurst \& New York, NY: Columbia University Press).

Hanifi, S. M. (2015) A Sampling of the Silences and Emphases in Mountstuart Elphinstone's Journey to Peshawar and An Account of the Kingdom of Caubul. Paper presented at the University of London School of Oriental and African Studies conference: Mountstuart Elphinstone and the Historical Foundations of Afghanistan Studies: Reframing Colonial Knowledge of the Indo-Persian World in the Post-Colonial Era, November 2015. 
Hopkins, B. D. (2008) The Making of Modern Afghanistan (London: Palgrave Macmillan).

Hyman, A. (2002) Nationalism in Afghanistan, International Journal of Middle East Studies, 34, pp. $299-315$.

Kushev, V. (1997) Areal Lexical Contacts of the Afghan (Pashto) Language (Based on the Texts of the XVI-XVIII Centuries), Iran \& the Caucasus, 1, pp. 159-166.

Kushev, V. (2001) The Dawn of Pashtun Linguistics: Early Grammatical and Lexicographical Works and Their Manuscripts, Mansuscripta Orientalia, 7(2), pp. 3-9.

Levi, S. C. (2002) The Indian Diaspora in Central Asia and Its Trade, 1550-1900 (Leiden: Brill).

Lindholm, C. (1980) Images of the Pathan: the usefulness of colonial ethnography, Archives Europeennes de Sociologie, 21(2), pp. 350-361.

Lockhart, L. (1958) The Fall of the Safavi Dynasty and the Afghan Occupation of Persia (Cambridge: Cambridge University Press).

Lockhart, L. (1993 [1938]) Nadir Shah: A Critical Study Based Mainly upon Contemporary Sources (Jalandhar, India: Asian).

Markovits, C. (2000) The Global World of Indian Merchants, 1750-1947: Traders of Sind from Bukhara to Panama (Cambridge: Cambridge University Press).

McChesney, R. D. \& Khorammi, M. (2016) The History of Afghanistan: Fayz Muhammad Katib Hazarah's Siraj al-tawarikh, 4 vols (Leiden; Boston: Brill).

Monsutti, A. (2005) War and Migration: Social Networks and Economic Strategies of the Hazaras of Afghanistan (London: Routledge).

Network of Concerned Anthropologists (2009) The Counter-Counter Insurgency Manual: Or, Notes on Demilitarizing American Society (Chicago, IL: Prickly Paradigm Press).

Noelle, C. (2010) The Abdali Pashtuns Between Multan, Qandahar and Heart, in: Marsden, M. \& Hopkins, B. (eds) Beyond Swat: History, Society, and Economy along the Afghanistan-Pakistan Frontier, pp. 31-38 (London: Hurst) and (New York, NY: Columbia University Press).

Poullada, L. B. (1970) The Pashtun Role in the Afghan Political System. Afghanistan Council of the Asia Society (New York, NY: The Afghanistan Council of the Asia Society).

Price, D. H. (2008) Anthropological Intelligence: The Deployment and Neglect of American Anthropology in the Second World War (Durham: Duke University Press).

Price, D. H. (2011) Weaponizing Anthropology: Social Science in Service of the Militarized State (Oakland and Petrolia, CA: CounterPunch and AK Press).

Said, E. (1994 [1979]) Orientalism (New York, NY: Vintage).

Singh, G. (1981 [1959]) Ahmad Shah Durrani: Father of Modern Afghanistan (Lahore: Tariq Publications).

Sourcewatch.org (nd) Tom Gouttierre. Available at: http://www.sourcewatch.org/index.php?title=Tom_Gouttierre. Accessed October 28, 2015.

Steensgard, N. (1999) The Route Through Qandahar: The Significance of Overland Trade between India and the West in the Seventeenth Century, in: Chaudhury, S. \& Morineau, M. (ed.) Merchants, Companies, and Trade: Europe and Asia in the Early Modern Era, pp. 55-73 (Cambridge: Cambridge University Press).

United States Army and Marine Corps (2007) Counterinsurgency Field Manual: U.S. Army Field Manual No. 3-24, Marine Corps Warfighting Publication No. 3-33.5 (Chicago, IL: University of Chicago Press).

United States Congress (1989) A Tribute to the Late Dr. Louis Dupree. Available at: http://www.jezail.org/02 essays/01fr_dupree.html. Accessed October 28, 2015.

Wink, A. (2002 (1991 and 1997)) Al-Hind: The Making of the Indo Islamic World. 2 vols (Leiden: E. J. Brill).

Worldcat.org (2010) Afghanistan. Available online at: https://www.worldcat.org/search?qt=worldcat_org_all\&q= Afghanistan, accessed March 2010. 